\title{
Contribution of the Magnetic Susceptibility to the Characterization of the Babouri-Figuil Cretaceous Basin
}

\author{
Augustin Désiré Balla Ondoa1*, Simon Ngos III $^{2}$, Emmanuel Ndjeng? \\ Alexis Nyangono Abolo ${ }^{3}$, Alexie N'Nanga ${ }^{3}$ \\ ${ }^{1}$ University of Ngaoundere, Ngaoundere, Cameroon \\ ${ }^{2}$ University of Maroua, Maroua, Cameroon \\ ${ }^{3}$ University of Yaounde I, Yaounde, Cameroon \\ Email: *augustelecompte2007@yahoo.fr, sngos@yahoo.com
}

Received 21 May 2014; revised 25 June 2014; accepted 10 July 2014

Copyright (C) 2014 by authors and Scientific Research Publishing Inc.

This work is licensed under the Creative Commons Attribution International License (CC BY).

http://creativecommons.org/licenses/by/4.0/

(c) (i) Open Access

\begin{abstract}
Magnetic susceptibility data from marine rocks can be used for global correlation due to synchronous variations in global erosion. This work, aims to show that, the magnetic susceptibility signature which exists in the cretaceous sediments of the Babouri-Figuil basin, resides mainly in the detrital constituents. Variations of amplitudes are observed, which can be useful for regional correlation. This amplitude variation results in the transgressive and regressive movements that give way to a fluctuation of detrital deposits because of erosion. Considering the sedimentological study, carried out, different microfacies have been identified in the basin, namely, fluvial facies and lake facies that sometimes contain fossils. The combination of detailed sedimentological analysis and sequence stratigraphy is based on the modeling of vertical and lateral variations within the basin. Finally, the interpretation of the magnetic susceptibility signal suggests that in the detrital domain, this signal is mainly controlled by environmental parameters such as the agitation of the water and the rate of sedimentation, as well as diagenesis.
\end{abstract}

\section{Keywords}

Magnetic Susceptibility, Sedimentology, Cretaceous, Detrital Constituents, Babouri-Figuil, Cameroon

\section{Introduction}

The Benue basin has a NE-SW direction, about 800 kilometers long from the Niger Delta to Lake Chad. In its "Corresponding author.

How to cite this paper: Balla Ondoa, A.D., Ngos III, S., Ndjeng, E., Nyangono Abolo, A. and N'Nanga, A. (2014) Contribution of the Magnetic Susceptibility to the Characterization of the Babouri-Figuil Cretaceous Basin. Open Journal of Soil Science, 4, 272-283. http://dx.doi.org/10.4236/ojss.2014.48029 
northern part, it is divided into two branches: that of Gongola, NS direction and that of Yola, with EW direction, and extends to Cameroon, where it corresponds to the small basins of Cretaceous continental sediments in Adamawa (Djerem, Mbéré) and Northern Cameroon (Mayo Rey, Hamakoussou, Mayo Oulo-Lere and Babouri-Figuil) (Figure 1). The last basin, focus and object of the present study, has a length of $33.5 \mathrm{~km}$ and $7.5 \mathrm{~km}$ wide.

The interest of this study lies on the geodynamic context of the setting of the Babouri-Figuil basin in the Benue Through. The northern part of the basin, is mainly filled by sandstone detrital sediments (coarse, medium, fine), which evolve to the south in marl, clays and limestone, supposing some specific environmental conditions of sedimentation. Therefore, it is essential to carry out a detailed sedimentological study of the different layers of the basin, in order to understand the deposition conditions. The signal from the magnetic susceptibility has been interpreted as related to detrital supplies and proximity with the source of these contributions. These parameters themselves are being related to climate variations [1]-[6]. Marine regression induces an increase in continental erosion which will increase the supply of erosion products in marine sediments and results in the increase of the magnetic susceptibility values [7]-[9]. Climate also affects the flow of magnetic susceptibility, and the increase of the rainfall increases the rate of erosion. The magnetic susceptibility is thus used as a tool for correlations between or inside sedimentary series [10] [11] and also as a climate and eustatic indicator [12] [13]. The purpose of this study is to highlight the relationship between the stratigraphy and sedimentology by applying the magnetic susceptibility method on the Cretaceous sediments of Babouri-Figuil basin. The first step will be the description of different sedimentological and paleontological facies of the Babouri-Figuil basin, and then we will examine the tectonic aspects. Finally, we will compare the sedimentological evolution with magnetic susceptibility. Here, the measures SM on a basin set up in a period of great climatic upheaval with numerous (Cretaceous-Tertiary extinction) will be tested.

\section{Geological Setting}

Different outcrops observed in the basin arranged as a syncline (Figure 2) consist of arkosic sandstone and coarse ferruginous sandstone at the base, with some conglomerate layers unconformably lying on the base in the northern edge of the basin [15] [16]. The average dip of the strata to the south is between $15^{\circ}$ and $25^{\circ}$. Above the sandstone, come the marly shale layers with a dip of $30^{\circ}-35^{\circ}$ south. The apical layers are conglomeratic sandstones while the lower layers are calcareous clay affected by fault throughout the basin borders to the south (Figure 2). The thickness of sediments sometimes reaches 1500 meters. The eastern sinking of the basin seems to be contemporaneous to sedimentation, contrary to the alternation of energy during the deposition.

In the Babouri-Figuil basin oil shale have been discovered in several places, two layers of one meter thick plunge to the south at an angle of $30^{\circ}$. They contain the remains of fish (Lepidotus manni), ostracods (Cypris

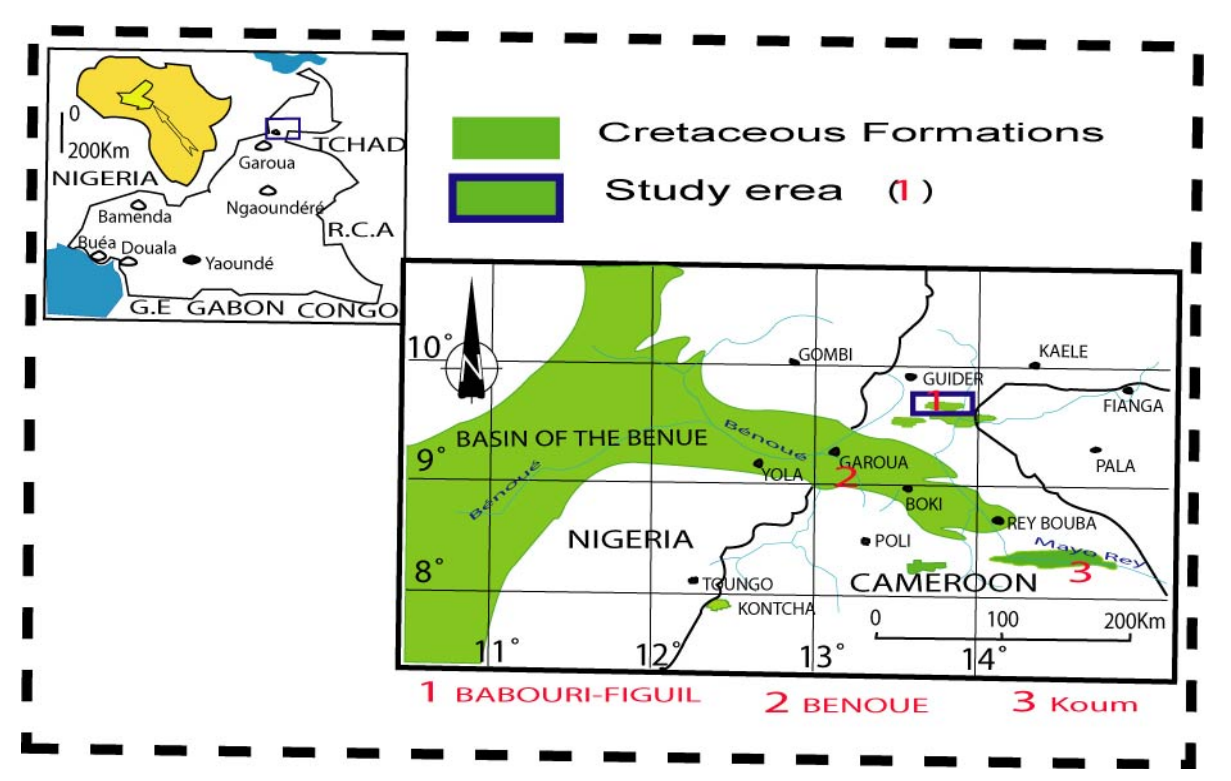

Figure 1. Location of the study area ([14], modified). 


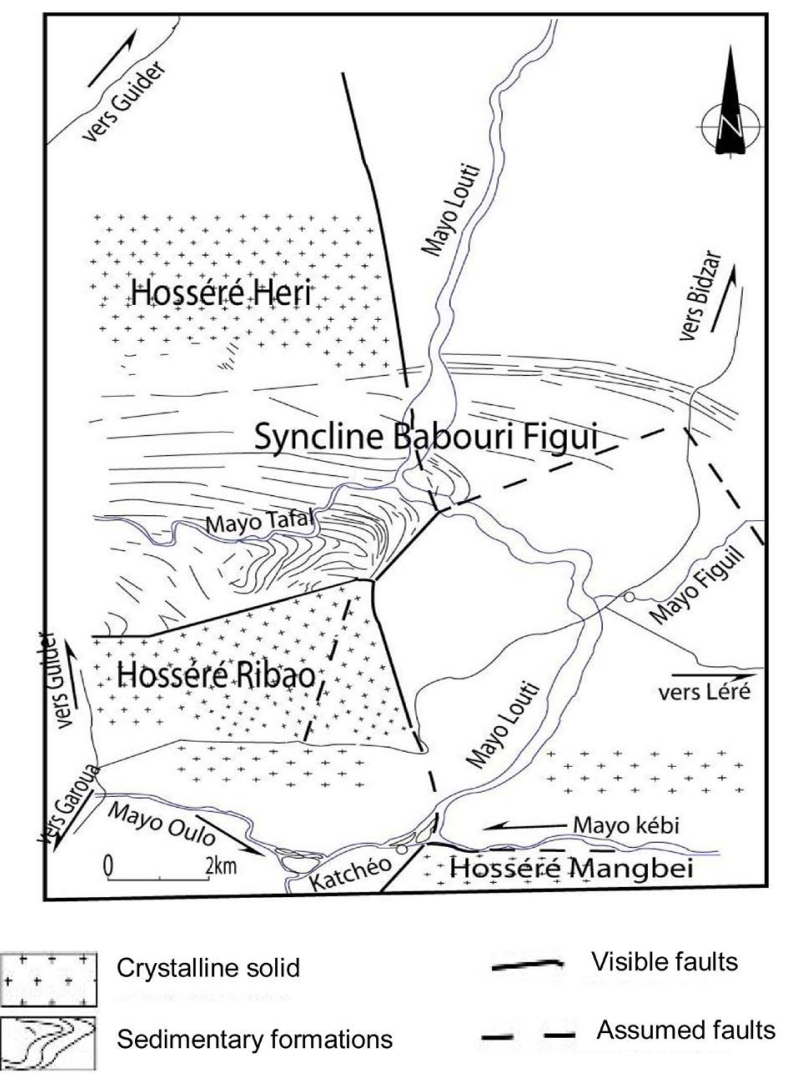

Figure 2. Eastern termination of syncline Babouri-Figuil [17], modified.

purbeckensis) and conchostracées (Estheria mawsoni, Estheriella tricostata and Estheriella camerouni) probably dating from the Neocomian, lake. Among the plants, Executioner in [13] recognized Pagiophyllum aff. crassifolium and Frenelopesis hohenggeri of the Lower Cretaceous.

\section{Materials and Methods}

Macroscopic and microscopic analysis (50 thin sections) from five outcrops (Mayo Louti, Mayo Figuil, Mayo Tafal, Sorawel-Lombel and Babouri) within the Babouri-Figuil basin, leads to a sedimentological model.

270 samples were performed, with a maximum distance of $1.5 \mathrm{~m}$ between each sample. For each sample, the magnetic susceptibility measurements were carried out. These measures correspond to the mass magnetic susceptibility (K corresponding to an average of three measurements, multiplied by a reference volume of $1 \mathrm{~m}^{3}$ and divided by the mass of the sample) and are expressed in $\mathrm{m}^{3} / \mathrm{kg}$. These measurements were performed on Kappabridge KLY-3S (University of Liege) on samples of a maximum volume of $2.5 \mathrm{~cm}^{3}$ the obtained data, magnetic susceptibility curves have been built and compared with microfacies curves; they were also used to establish correlation cuts [7] [9] [10] [18]-[20].

\section{Results and Discussion}

\subsection{Facies and Paleoenvironment}

Careful and complete lithologic and sedimentological study of Babouri-Figuil basin has been eased by dividing the basin into three parts: East, Central, and West.

Sedimentary outcrops in the eastern part of the basin are presented on the Mayo Figuil and the Mayo Louti sections. The outcrop of Mayo Figuil is made up from bottom to top by: a conglomeratic unit at the base, consisting of large blocks of coarse conglomeratic sandstone with worn and concentrated in small shoals pebbles. The cement phase consists in an indurated green argillite and ferruginized sandstone benches at the base, grey at 
the top and well cemented by silica, making them very hard in contact with the hammer. A suite of coarse sandstone benches overhang these layers. A clayey-limestone unit covered by alluvial deposits at its base then appears, constituted of shales, more or less indurated compact clays interspersed with limestone layers and finally a calcareous marl unit essentially consisting of calcite shale, oil shale and marl. A calcareous marl unit is constituted of alternating layers of marl thick shale layers intercalating small layers of crystalline limestone and siltstone containing extraclasts and septaria. Finally bituminous marl unit or consisting essentially of oil shale and calcite-rich shale and marl bearing joints steering WNW.

Mayo Louti outcrop is made up from bottom to top of a sequence of silty sandstone and, laminar and iron-rich at the base, and gray at the top. It is partially calcitized and includes sandstone or carbonate pisolites. Some layers have ripple marks, others include clasts (Figure 3(A)). Top alternating banks of silty ocher sandstone calcified in past septaria (Figure 3(B)). These series are interspersed with thick layers of marl shale. Sediments contains numerous brachiopods (Estheria mawsoni Estheriella tricostata and Estheriella Camerouni), more over plant footprints attributed to the genus Brachyphyllum and leaflets Zamites types have also been identified [21]. Silicified wood was also observed (Figure 3(C)).

Sedimentary outcrops of the Centre of the basin gather in the Mayo Tafal and between Hossere Sorawel and Hossere Lombel. The monotonous Mayo Tafal outcrops are constituted essentially of an alternation from bottom to top by: marl shale, limestone, siltstone, sandstone and some layers of shale. All these layers are strongly calcified. Some layers are illustrated by a lateral facies change schistose marl at the periphery limestone. Microlaminations and laminations observed in some layers (siltstone, sandstone) reflect a sediment deposition from a low to medium energy transport.

The outcrop located between Hosséré Sorawel and Hosséré Lombel, shows medium and fine calcareous layers, benches siltstone and schistose green marl. Many subcircular dinosaur footprints were discovered in a sandstone slab [17] [21]. The flora is similar to that found in the Eastern formations of the basin.

The sedimentary evolutions in the western part of the Babouri-Figuil basin shows at the base sandstone deposit and then marl deposits. Marl layers are metamorphosed in some places or affected by contact metamorphism related to post-volcanic episodes. Remains of fish and Actinistiens Actinopterygii were identified [17], as well as several fragments remain of crocodiles [22].

The mineralogy of various facies is quite uniform throughout the basin. The quartz grains are abundant in the different sandstone (Figure 3). Almost of them are very dull and reflect a low energy environment and transport courses. Feldspars are also quite represented but impaired pushed actions hydrolysantes sediment leaving a cloudy appearance under the microscope. However, anytime some plagioclase twinning remains well observable. Many flakes of muscovites and amphibole minerals are also present in the basin. The other constituents are clay minerals constituting a procession comprising: chlorite, kaolinite, smectite to which may be added the interbedded Mica/ smectite [17]. All these minerals may be inherited from detrital products having supplied the early Cretaceous basin.

\subsection{Sedimentary Structures}

Most of the sedimentary structures observed in the Babouri-Figuil basin are from hydrodynamic origin. They represent the response of a loose sediment to the intensity and direction of a current. The combination of various structures and their frequency allow, from a lithological context, paleontological view of a given sedimentary sequence, to clarify the depositional environment. Different sedimentary structures, selected are: directional structures, non-directional structures, gravity structures dry sediment deformation structures. The most common sedimentary structures found in the Babouri-figuil basin are ripple marks; they display a great variety (wrinkle symmetric waves, asymmetrical lines, special lines, complex wrinkles).

Desiccation and compaction waterlogged produce sludge system slots that draw a network of polygon on the surface of the sediment. These polygons have different forms and layout of slots is straight or slightly curved. The surfaces with well-developed desiccation cracks show a hierarchy of network slot (Figure 4(e)). The desiccation cracks indicate a low deep aquatic environment temporarily emerged. They are indications of sedimentation occurring near or at the surface, as well as climatic periods alternately wet and dry.

The convoluted Mayo Tafal primary laminae are deformed; they generally have relatively narrow ridges and loose hollow. Their genesis may be related to the liquefaction of sediment [23]. They may indicate a fluvial environment.

The different figures of ithological synthesis of the Babouri-Figuil basin can lead to different paleoenviron- 

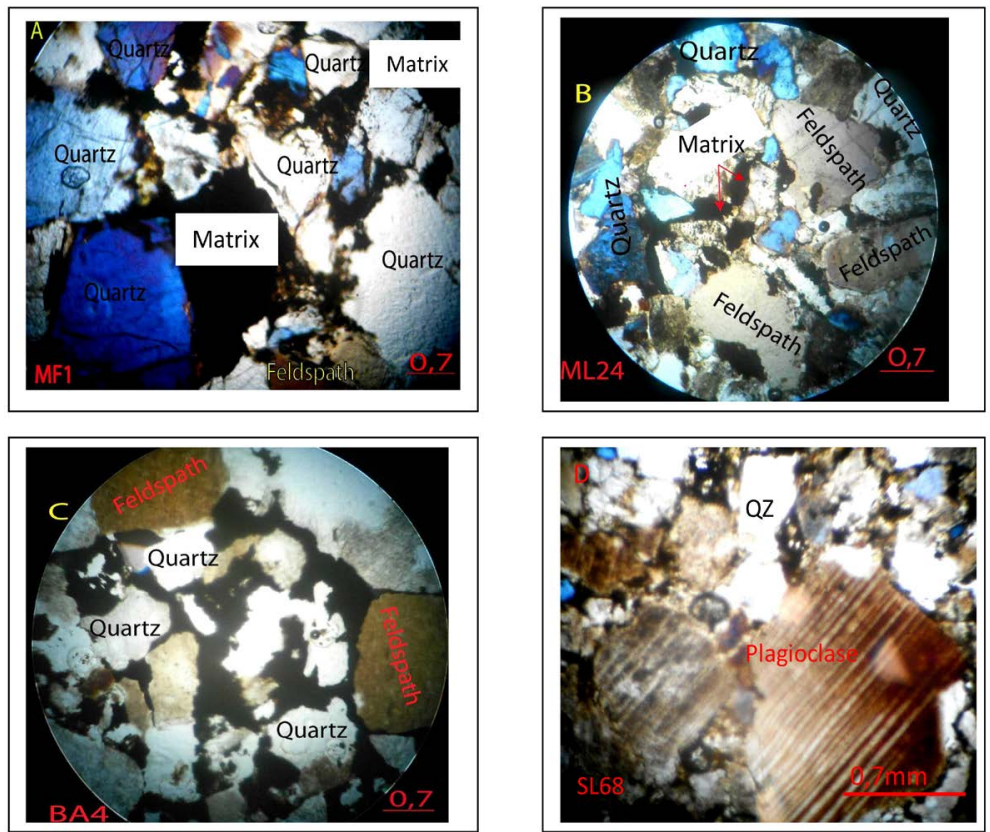

Figure 3. (A)-(D) illustrate the abundance of grains of quartz and feldspar in the Babouri-Figuil basin.

mental interpretations. The presence of abundant flora, marked by plant footprints in different sediments layers of Babouri-Figuil basin, indicate that the sedimentation took place in a shallow water environment. The plethora of wildlife described by some authors as well as huge deposits of fine sediments to the south of the basin, may indicate a continental depositionnal environment (lacustrine, fluvial), under a seasonal climate as attested by the abundance of dry-type sediment structures in the various formations of the basin.

\subsection{Evolution of Microfacies and Magnetic Susceptibility Curves}

The curve of magnetic susceptibility (MS) of the Mayo Figuil outcrop of eastern part of the basin shows six patterns with early regression, which correspond to an increase of the values of MS to $4.81 \times 10^{-8} \mathrm{~m}^{3} / \mathrm{kg}$, followed by a transgression of aggrading corresponding to low values in the order of $1.73 \times 10^{-8} \mathrm{~m}^{3} / \mathrm{kg}$ to $1.80 \times 10^{-8}$ $\mathrm{m}^{3} / \mathrm{kg}$. Then a slight decline is accompanied by a sharp fall in values of MS suggesting a transgression (Figure 5). Brief MS values oscillate between 1.52 and $4.81 \times 10^{-8} \mathrm{~m}^{3} / \mathrm{kg}$. In the Mayo Louti outcrop, more than a dozen trends are represented in two sections, and curves are presented almost at the same face. It appears that all these curves present the same evolution of the transgressive and regressive trends. However, the basis of this essential sandstone section has a portion of the curve in opposition microfacies curve in opposition to MS after aggradation that comes together in a short transgression and regression with low values MS $\left(\sim 6.23 \times 10^{-8} \mathrm{~m}^{3} / \mathrm{kg}\right)$. SM values are generally positive and quite high, sometimes reaching the peak value of $12.3 \times 10^{-8} \mathrm{~m}^{3} / \mathrm{kg}$.

Outcrop of Mayo Tafal (Figure 4) shows a lithological curve which oscillates regularly and has several transgressive and regressive trends. This oscillates in parallel with the MS curve which has almost the same tendencies. MS show a wider range of values very high In general ranging from $0.00004 \times 10^{-8}$ to $66.2 \times 10^{-8} \mathrm{~m}^{3} / \mathrm{kg}$. The microfacies evolution curve in Sorawel-Lombel section (Figure 5) has at its base a very short aggradation which corresponds to two transgressive phases and two regressive phases of the MS curve. High downward trend based on the curve comes together with the MS. From this point of view, five successive general trends are observed simultaneously in the evolution of the two curves: three trends in opposition and two parallel trends. MS values that are observed range from $0.30 \times 10^{-8}$ to $13.9 \times 10^{-8} \mathrm{~m}^{3} / \mathrm{kg}$.

The Babouri cut to the west basin shows five trends. The base and $3 / 5$ of the top of the curve are characterized by a marked parallelism between the curves of microfacies and MS. While the second section of the microfacies curve, from the base has an evolution in opposition to the SM curve. MS values observed range from $0.039 \times 10^{-8}$ to $18.8 \times 10^{-8} \mathrm{~m}^{3} / \mathrm{kg}$. 

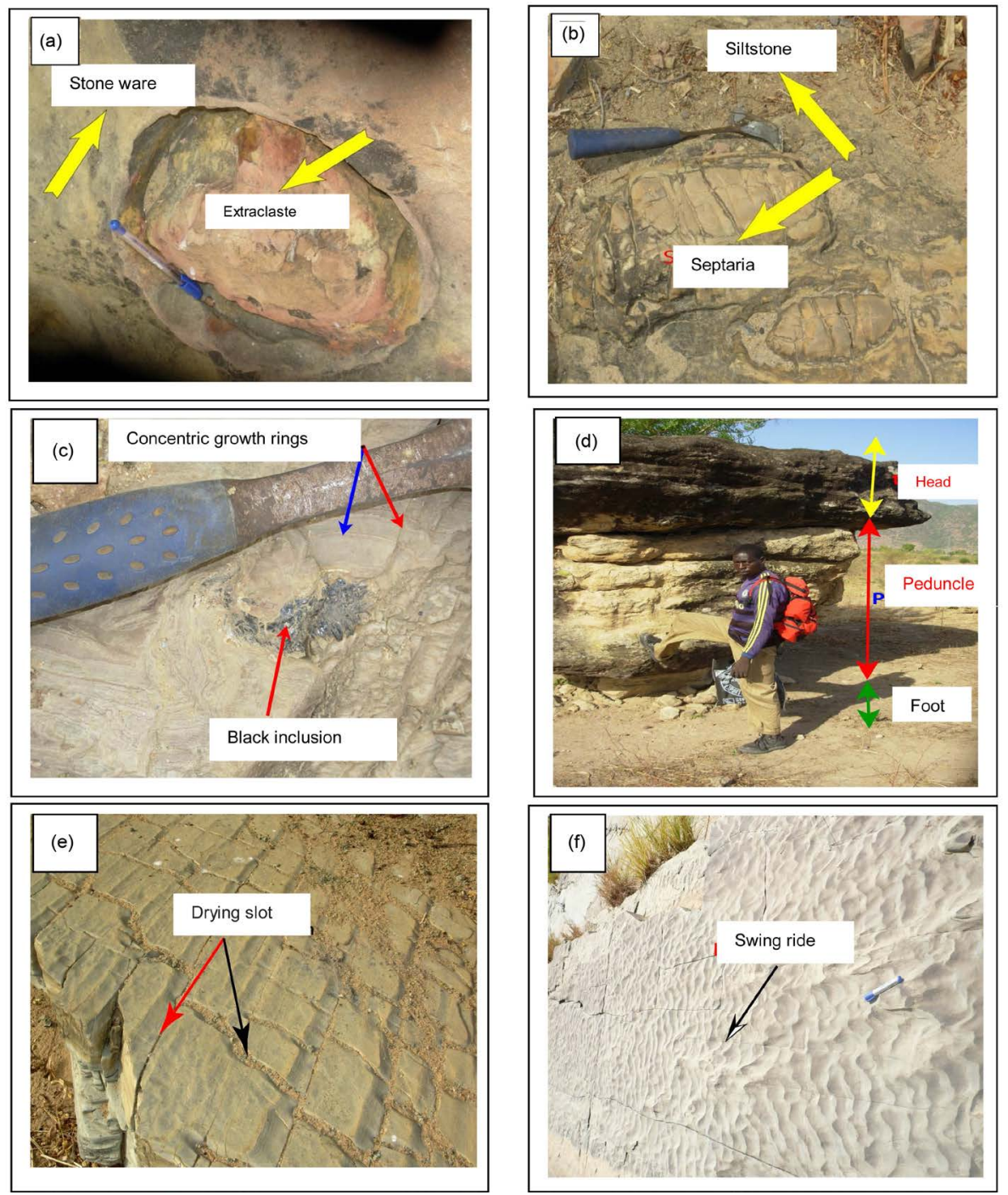

Figure 4. (a) Extraclast ball in a fine sandstone; (b) Septaria balls in a siltstone; (c) Petrified wood showing growth rings; (d) Rock Hoodoo; (e) Volcanic Babouri prisms; (f) Swing ride Mayo Tafal.

\subsection{Correlation}

The analysis of the magnetic susceptibility curves of five (05) sections in the Babouri-Figuil basin led to the identification of some relatively complex situations involving some of these cuts. Indeed, there is not a unique behavior which seems to be emerging from all these different cuts. Some show a contrast between the microfacies curves and the magnetic susceptibility due to the decrease or increase in the values of magnetic susceptibility (Figure 5: MF, SL). These microfacies trends evolve according to transgressive and regressive trends. They are set up in processions of transgressive and regressive deposits. Within these deposits, so-called "limit of the stirring zone" surface was identified. In other parts of the basin, the parallelism prevails in some places with increasing values of MS (Figure 5: Bab, ML, and MT).

\subsection{Sedimentology Parameters and Magnetic Susceptibility}

Many parameters may be involved in changes in magnetic susceptibility. We tried to observe the evolution of the magnetic susceptibility in relation with the type of microfacies. Three main deposition parameters were considered. 

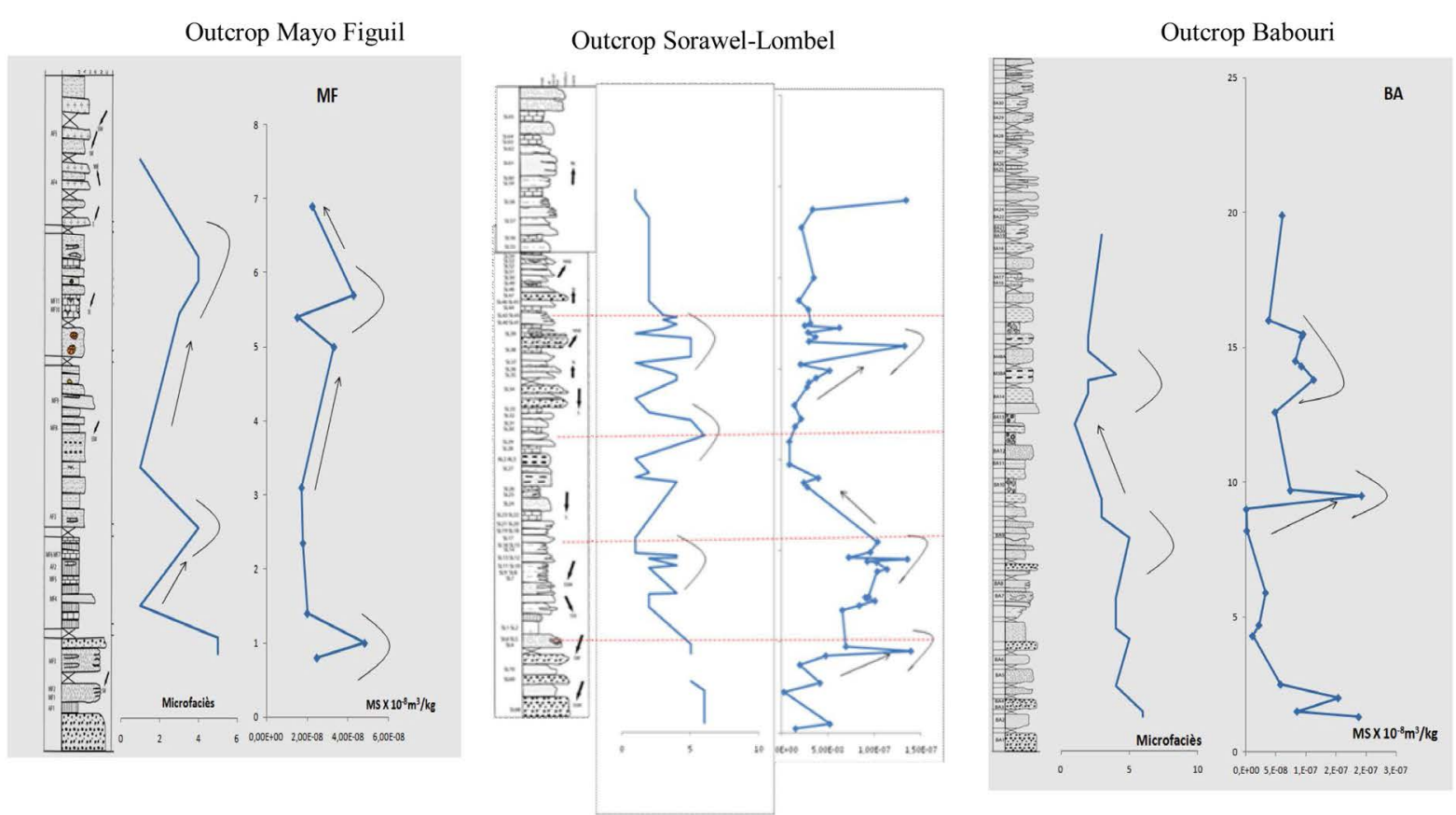

Outcrop Mayo Louti

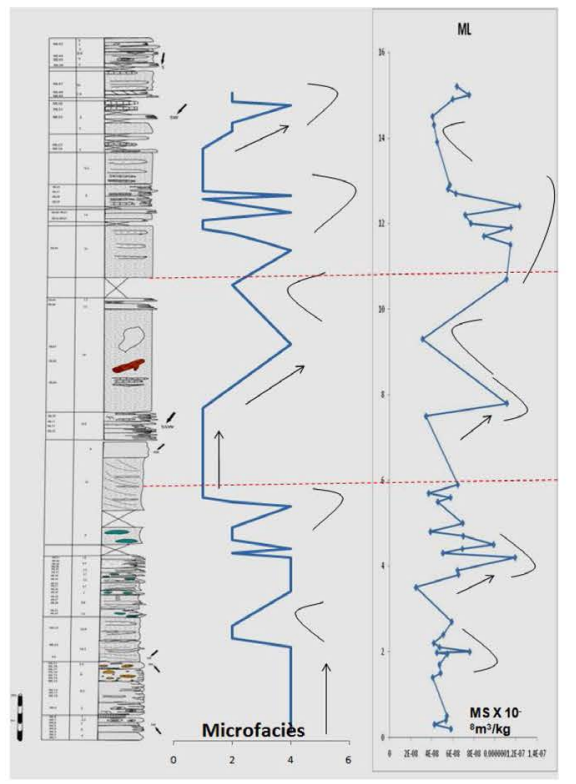

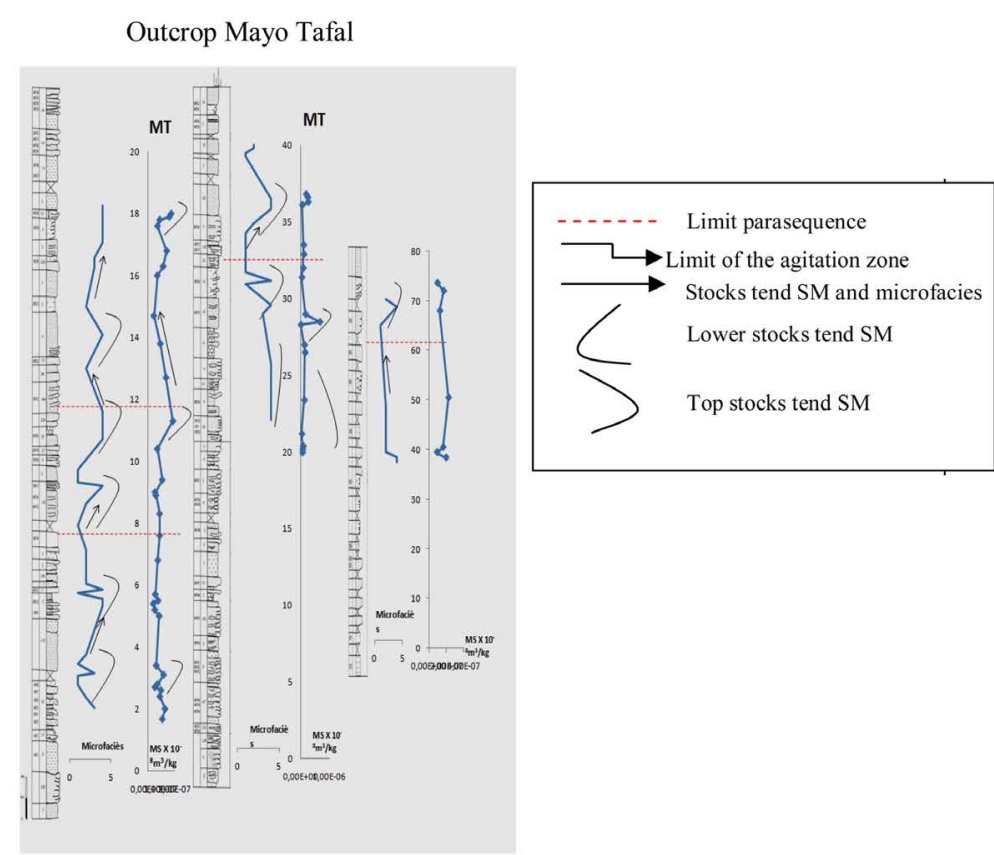

Figure 5. Correlation outcrops of Babouri-Figuil basin based sequence stratigraphy.

The first parameter is the sedimentation rate which trends are well defined in the literature [24] [25], assuming that the magnetic susceptibility is under the influence of detritism; if it is similar within two microfacies, the value of the magnetic susceptibility is dominated a bit by the largest production of carbonate than the other [26].

The second parameter is the turmoil. Here it is estimated by the texture of microfacies. More turmoil is important; more sedimentation of fine particles of magnetic carrier signal is weak.

The third parameter is a semi-quantitative evolution of terrigenous quartz in each microfacies. Although quartz mineral diagenesis is not itself carrying the magnetic signal, it can be considered as a good indicator of detrital at whole [27].

While these three parameters are related, agitation such conditions as the rate of sedimentation and detrital in- 
fluence. However, these three parameters seem not to have the same influence on the magnetic susceptibility, and that, depending on the deposition medium.

The mean values of magnetic susceptibility in the formation of the east of the basin (Mayo Figuil) are shown in Figure 6. This is also the cut that has fewer microfacies. It shows a trend of continuous increase (but with a slight inflection at the fine sandstone): average magnetic susceptibility values range from $2.33 \times 10^{-8} \mathrm{~m}^{3} / \mathrm{kg}$ for acl $/ \mathrm{arg}$. $3.66 \times 10^{-8} \mathrm{~m}^{3} / \mathrm{kg}$ for Qm. Microfacies cup of the Mayo Louti (Figure 6) show a tendency to increase the values of the magnetic susceptibility of the schistose marl clays $\left(5.27 \times 10^{-8}\right.$ to $8.66 \times 10^{-8} \mathrm{~m}^{3} / \mathrm{kg}$ ). Falling values of magnetic susceptibility (MS) at the fine sandstone $\left(5.58 \times 10^{-8} \mathrm{~m}^{3} / \mathrm{kg}\right)$ is recorded over the value of $\mathrm{SM} \mathrm{cal/arg}$. It is important to note that in this part of the basin; the magnetic susceptibility values remain generally higher, reaching their peak on schistose marl (MSCH).

Mayo Tafal outcrop (central of the basin) which has a sedimentation in general monotonous, Figure 6 shows the fairly high average values of magnetic susceptibility $\left(8.71 \times 10^{-8} \mathrm{~m}^{3} / \mathrm{kg}\right)$ at cal/arg. They gradually increase to reach $12.1 \times 10^{-8} \mathrm{~m}^{3} / \mathrm{kg}$ on schistose marl, and a slight decrease is observed in the value of MS on fine sandstone $\left(11.6 \times 10^{-8} \mathrm{~m}^{3} / \mathrm{kg}\right)$. The mean values of magnetic susceptibility presented in Figure 6 (Sorawel-Lombel) are relatively high. The shape of the curve has one identical the outcrop Mayo Louti scalable characteristic. The growing trend in the first phase reaches its maximum value $\left(6.74 \times 10^{-8} \mathrm{~m}^{3} / \mathrm{kg}\right)$ on porcelain stoneware. This trend is to decrease the values of MS $\left(2.76 \times 10^{-8} \mathrm{~m}^{3} / \mathrm{kg}\right)$ at coarse sandstone for the second phase.

Babouri outcrop (Figure 6 western part of the basin) has the most complete range of microfacies and the average magnetic susceptibility values are very low. The evolution of the average values of MS based on microfacies is very tooth. There was an increase in the average value of magnetic susceptibility reaching $13.7 \times 10^{-8}$ $\mathrm{m}^{3} / \mathrm{kg}$ on coarse sandstone.
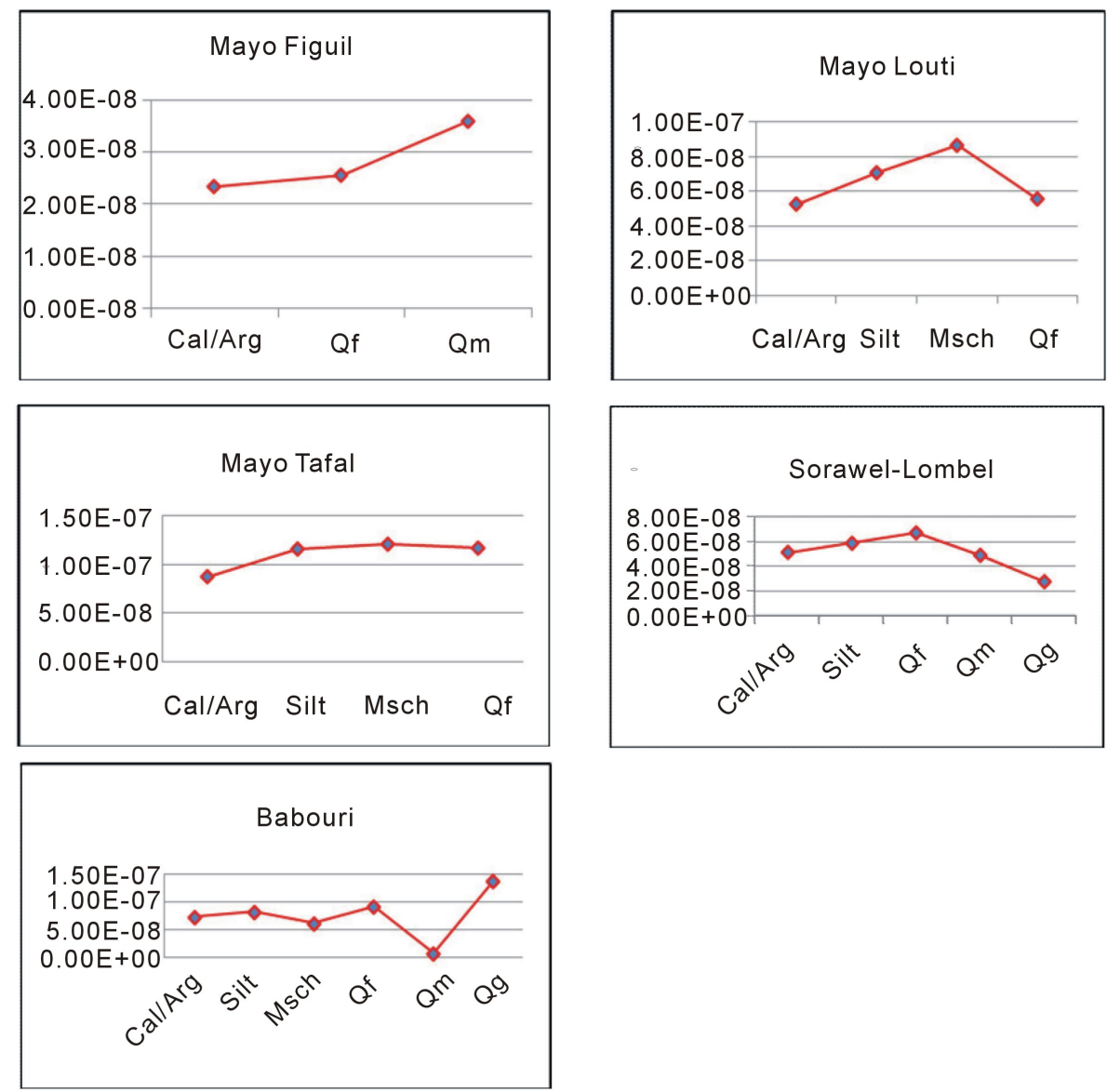

Figure 6. Mean values of magnetic susceptibility for each section. Each microfacies, data are the average value of magnetic susceptibility in the section and the number of samples (n). 


\section{Discussion}

The complex relationship between the evolution of microfacies curve and the magnetic susceptibility leads to believe that, contrary to the suggestion made by many authors [3] [7] [28] [20], variations in magnetic susceptibility values in different sections studied are not directly related to changes in water level. Transgressive trend of the curve of evolution of microfacies not automatically lead to a decrease in magnetic susceptibility values, as these authors suggest. A close look at the extreme values of the magnetic susceptibility curve of any associated cut lithology shows that, the highest MS values correspond most often, to sandstones facies. This could explain the strong impregnation of carbonates in the sandstone of Babouri-Figuil basin.

However, after comparing of sedimentological parameters and magnetic susceptibility, we can say that the raise of mean values of magnetic susceptibility is due to the very low agitation conditions for the settling of magnetic minerals. This approach helps to explain the differential behavior of the magnetic susceptibility curve vis-à-vis the microfacies curve. Thus, the model of Crick and Ellwood applies perfectly. Indeed, as the average values of MS continually increase in the fine deposits and decrease in the coarse deposits, any downward trend implies an increase in magnetic susceptibility values. This parallelism between the curves of magnetic susceptibility and that microfacies is observed on portions of all the different curves MS. Mayo Figuil Curve (Figure 6), which also presents the average values of SM raising on sandy facies more carbonated than at Babouri, suggests two hypotheses to explain this behavior: the mean values registered is high for MS carbonate sandstone linked with dolomitization basin [29] [30], or then this record of high values of MS in these sandstones could also be explained by pedogenesis. According to [31] magnetic minerals are formed during soil genesis.

Diagenesis can also influence the magnetic susceptibility signal by inducing a chemical remagnetization. This remagnetization usually transforms phyllites, smectite and illite [17] in the basin. The amount of illite formed here, obviously depends on the quantity of phyllite initially present in the rock. One can therefore infer that, this phenomenon is more developed in argillaceous rocks of the Babouri-Figuil basin. This transformation allows the formation of magnetic minerals (mainly magnetite) [32]. This phenomenon is also strengthening values MS, especially in clayey sediments.

The presence of numerous authigenic quartz grains (Figure 3) in the coarse sediment of the basin in general, could act in the same way that the dilution by carbonate production (diamagnetic) which is commonly evoked to explain the low values of MS in the bioconstructed facies [9] [11] [27] [33].

\section{Conclusions}

From this study, two types of environment have been identified: a fluvial environment with the presence of coarse sandstone and the presence of crocodile fossils; a lacustrine environment with the presence of plant footprints reported like Brachyphyllum as well as the Branchiopods (Estheria) coprolites which develop in a fine sedimentation

Among the different sedimentary structures, the most notable are the ripple marks and the desiccation cracks which indicate a permanent fluctuation blade water variety of current and long periods of interruption phases of sedimentation.

The analysis of the evolution curves of microfacies in different sections studied within the Babouri-Figuil basin indicates that these trends evolve in transgressive and regressive contexts. These microfacies were established in processions and transgressive-regressive deposits. Within these deposits, a surface called "limit of the stirring zone" was identified. This area characterizes an abrupt transition between the fluvial and lacustrine areas.

The signal from the MS is most related to the clay fraction and strongly influenced by lithology. Lithological variations (alternating sandstone/clay) are related to the agitation. Coarse laminae are deposited during high agitation periods while the fine laminae are deposited in the low agitation. We can therefore assume that in different studied sections the changes in mean values between MS laminae cal/arg and sandstone laminae are thus influenced by the agitation.

\section{Acknowledgements}

We thank the laboratory manager of sedimentary petrology from the University of Liege in Belgium Professor F. Boulvain and his colleague Anne Christine Da Silva for allowing us to perform analyzes of magnetic suscepti- 
bility. We also gratify entire research team deployed in the Babouri-Figuil basin with whom we walked in multidisciplinary research.

\section{References}

[1] Robinson, S.G. (1993) Lithostratigraphic Applications for Magnetic Susceptibility Logging of Deep-Sea Sediment Cores: Examples from ODP Leg 115. In: Hailwood, E.A. and Kidd, R.B., Eds., High Resolution Stratigraphy, Geological Society Special Publication, 65-98.

[2] Curry, W.B., Schneider, D.A. and Party, L.S. (1995) Ceara Rise Sediments Document Ancient Climate Change. EOS, 76, 41-45.

[3] Crick, R.E., Ellwood, B.B., El Hassani, A. and Feist, R. (2000) Proposed Magnetostratigraphy Susceptibility Magnetostratotype for the Eifelian-Givetian GSSP (Anti-Atlas, Morocco). Episodes, 23, 93-101.

[4] Arai, K., Sakai, H. and Konishi, K. (1997) High-Resolution Rock-Magnetic Variability in Shallow Marine Sediment: A Sensitive Paleoclimatic Metronome. Sedimentary Geology, 110, 7-23. http://dx.doi.org/10.1016/S0037-0738(96)00082-6

[5] Lean, C.M.B. and McCave, I.N. (1998) Glacial to Interglacial Mineral Magnetic and Palaeoceanographic Changes at Catham Rise, SW Pacific Ocean. Earth and Planetary Science Letters, 163, 247-260. http://dx.doi.org/10.1016/S0012-821X(98)00191-5

[6] Da Silva, A.C. and Boulvain, F. (2006) Upper Devonian Carbonate Platform Correlations and Sea Level Variations Recorded in Magnetic Susceptibility. Palaeogeography, Palaeoclimatology, Palaeoecology, 240, 373-388. http://dx.doi.org/10.1016/j.palaeo.2006.02.012

[7] Crick, R.E., Ellwood, B.B., El Hassani, A., Feist, R. and Hladil, J. (1997) Magnetosusceptibility Event and Cyclostratigraphy (MSEC) of the Eifelian-Givetian GSSP and Associated Boundary Sequences in North Africa and Europe. Episodes, 20, 167-175.

[8] Racki, G., Racka, M., Matyja, H. and Devleeschouwer, X. (2002) The Frasnian/Famennian Boundary Interval in the South Polish-Moravian Shelf Basins: Integrated Event-Stratigraphical Approach. Palaeogeography, Palaeoclimatology, Palaeoecology, 181, 251-297. http://dx.doi.org/10.1016/S0031-0182(01)00481-3

[9] Da Silva, A.C., Mabille, C. and Boulvain, F. (2009) Influence of Sedimentary Setting on the Use of Magnetic Susceptibility: Examples from the Devonian of Belgium. Sedimentology, 56, 1292-1306. http://dx.doi.org/10.1111/j.1365-3091.2008.01034.x

[10] Ellwood, B.B., Crick, R.E., El Hassani, A., Benoist, S.L. and Young, R.H. (2000) Magnetosusceptibility Event and Cyclostratigraphy Method Applied to Marine Rocks: Detrital Input versus Carbonate Productivity. Geology, 28, 11351138. http://dx.doi.org/10.1130/0091-7613(2000)28<1135:MEACMA>2.0.CO;2

[11] Da Silva, A.C., Potma, K., Weissenberger, J.A.W., Whalen, M.T., Humblet, M., Mabille, C. and Boulvain, F. (2009) Magnetic Susceptibility Evolution and Sedimentary Environments on Carbonate Platform Sediments and Atolls, Comparison of the Frasnian from Belgium and Alberta, Canada. Sedimentary Geology, 214, 3-18. http://dx.doi.org/10.1016/j.sedgeo.2008.01.010

[12] Ellwood, B.B., Tornkin, J.H., El Hassani, A., Bultynck, P., Brett, C., Schindler, E., Feist, R. and Bartholomew, A.J. (2011) A Climate-Driven Model and Development of a Floating Point Time Scale for the Entire Middle Devonian Givetian Stage: A Test Using Magnetostratigraphy Susceptibility as a Climate Proxy. Palaeogeography, Palaeoclimatology, Palaeoecology, 304, 85-95.

[13] Devleeschouwer, X., Petitclerc, E., Spassov, S. and Préat, A. (2010) The Givetian-Frasnian Boundary at Nismes Parastratrotype (Belgium): The Magnetic Susceptibility Signal Controlled by Ferromagnetic Minerals. Geologica Belgica, 13/4, 345-360. http://dx.doi.org/10.1016/j.palaeo.2010.10.014

[14] Bessong, M. (2012) Paléoenvironnement et diagenèse dans un réservoir gréseux d’âge Crétacé du fossé de la Bénoué au Nord Cameroun: les grès de Garoua.

[15] Roch, E. (1953) Itinéraires géologique dans le Nord du Cameroun et le Sud—Ouest du territoire du Tchad. Bulletin du service des Mines, 1, 1-110.

[16] Schwoerer, P. (1965) Notice explicative sur la feuille de Garoua-Est. Carte géologique de reconnaissance au 1/500,000. Direction des Mines et de la Géologie, 49.

[17] Ndjeng E. (1992) Modèle d'évolution géodynamique de deux bassins Crétacé inférieur du Nord-Cameroun: BabouriFiguil et Mayo Oulo-léré. Thèse d’Etat Université de Yaoundé, 311.

[18] da Silva, A.C. and Boulvain, F. (2002) Sedimentology, Magnetic Susceptibility and Isotopes of a Middle Frasnian Carbonate Platform: Tailfer Section, Belgium. Facies, 46, 89-102. http://dx.doi.org/10.1007/BF02668075

[19] Crick, R.E., Ellwood, B.B., Hladil, J., El Hassani, A., Hrouda, F. and Chlupác, I. (2001) Magnetostratigraphy Suscep- 
tibility of the Pridolian-Lochkovian (Silurian-Devonian) GSSP (Klonk, Czech Republic) and a Coeval Sequence in Anti-Atlas Morocco. Palaeogeography, Palaeoclimatology, Palaeoecology, 167, 73-100. http://dx.doi.org/10.1016/S0031-0182(00)00233-9

[20] Ellwood, B.B., Crick, R.E. and El Hassani, A. (1999) The Magneto-Susceptibility Event and Cyclostratigraphy (MSEC) Method Used in Geological Correlation of Devonian Rocks from Anti-Atlas Morocco. The American Association of Petroleum Geologists Bulletin, 83, 1119-1134.

[21] Dejax, B. (1989) Les flores fossiles du bassin d’Hamakoussou, Crétacé inférieur du Nord Cameroun. Géologie de l'Afrique et de l'Atlantique Sud.

[22] Michard, J.C., De Broin, F., Brunet, M. and Hell, J. (1990) Le plus ancien crocodilien néosuchien spécialisé à caractère “eusuchien” du continent africain (Crétacé inférieur, Cameroun). t. 311, série II, Comptes rendus de l’Académie des sciences, Paris, 365-371.

[23] Cojan, I. and Thiry, M. (1992) Seismically Induced Deformation Structures in Oligocène Sballow-Marine and Aeolian Coastal Sands (Paris Basin). Tectonophisic, 206, 79-89. http://dx.doi.org/10.1016/0040-1951(92)90369-H

[24] McNeill, D.F. (2005) Accumulation Rates from Well-Dated Neogene Carbonate Platforms \& Margins. Sedimentary Geology, 175, 73-87. http://dx.doi.org/10.1016/j.sedgeo.2004.12.032

[25] Quinquerez, A., Allemand, P., Dromart, G. and Garcia, J.P. (2004) Impact of Storms on Mixed Carbonate and Siliciclastic Shelves: Insights from Combined Diffusive and Fluid-Flow Transport Stratigraphic forward Model. Basin Research, 16, 431-449. http://dx.doi.org/10.1111/j.1365-2117.2004.00247.x

[26] Da Silva, A.C., Mabille, C. and Boulvain, F. (2009) Influence of Sedimentary Setting on the Use of Magnetic Susceptibility: Examples of the Devonian of Belgium. Sedimentology, 56, 1292-1306.

[27] Mabille, C. and Boulvain, F. (2007) Sedimentology and Magnetic Susceptibility of the Upper Eifelian-Lower Givetian (Middle Devonian) in SW Belgium: Insights into Carbonate Platform Initiation. Geological Society of London, Special Publication, 275, 109-123.

[28] Crick, R.E., Ellwood, B.B. and El Hassani, A. (1994) Integration of Biostratigraphy, Magnetic Susceptibility and Relative Sea-Level Change: A New Look at High Resolution Correlation. Subcommission on Devonian Stratigraphy, Newsletter, 11, 59-66.

[29] Bityukova, L., Shogenova, A. and Götze, H.J. (1998) Influence of Chemical Composition on Petrophysical Properties of Early Paleozoic Carbonate Rocks in Estonia. Physics and Chemistry of the Earth, 23, 309-316.

[30] Shogenova, A. (1999) The Influence of Dolomitization on the Magnetic Properties of Lower Palaeozoic Carbonate Rocks in Estonia. Geological Society of London, Special Publication, 151, 167-180. http://dx.doi.org/10.1144/GSL.SP.1999.151.01.17

[31] Tile, M.S. and Linington, R.E. (1975) Effect of Climate on the Magnetic Susceptibility of Soils. Nature, 256, 565-566. http://dx.doi.org/10.1038/256565a0

[32] Riquier, L., Averbuch, O., Devleeschouwer, X. and Tribovillard, N. (2010) Diagenetic versus Detrital Origin of the Magnetic Susceptibility Variations in Some Carbonate Frasnian-Famennian Boundary Sections from Northern Africa and Western Europe: Implications for Paleoenvironmental Reconstructions. International Journal of Earth Sciences, 99, 57-73. http://dx.doi.org/10.1007/s00531-009-0492-7

[33] Mabille, C. and Boulvain, F. (2007) Sedimentology and Magnetic Susceptibility of the Couvin Formation (Eifelian, South Western Belgium): Carbonate Plateform Initiation in a Hostile World. Geologica Belgica, 10, 47-67. 


\section{Abbreviations and Definition}

Mayo: River in the vernacular (Foufoulde) in Cameroon

MF: Mayo-figuil

ML: Mayo louti

MT: Mayo tafal

SL: Sorawel-lombel

BA or Bab: Babouri

Msch: Schistose marl

SM: Magnetic Susceptibility

Qm: Medium Sandstone

Silt: Siltstone

Qf: Fine sandstone

Cal: Limestone

Arg: Clay, argillite

Qg: Coarse sandstone 
Scientific Research Publishing (SCIRP) is one of the largest Open Access journal publishers. It is currently publishing more than 200 open access, online, peer-reviewed journals covering a wide range of academic disciplines. SCIRP serves the worldwide academic communities and contributes to the progress and application of science with its publication.

Other selected journals from SCIRP are listed as below. Submit your manuscript to us via either submit@scirp.org or Online Submission Portal.
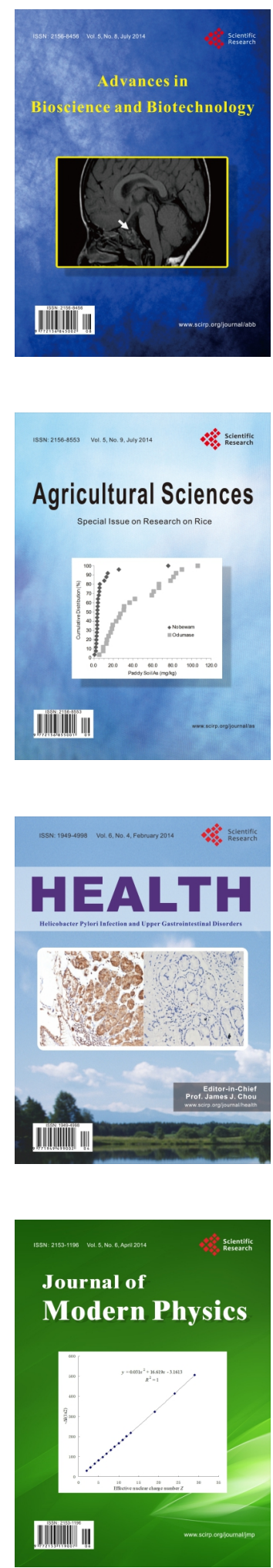
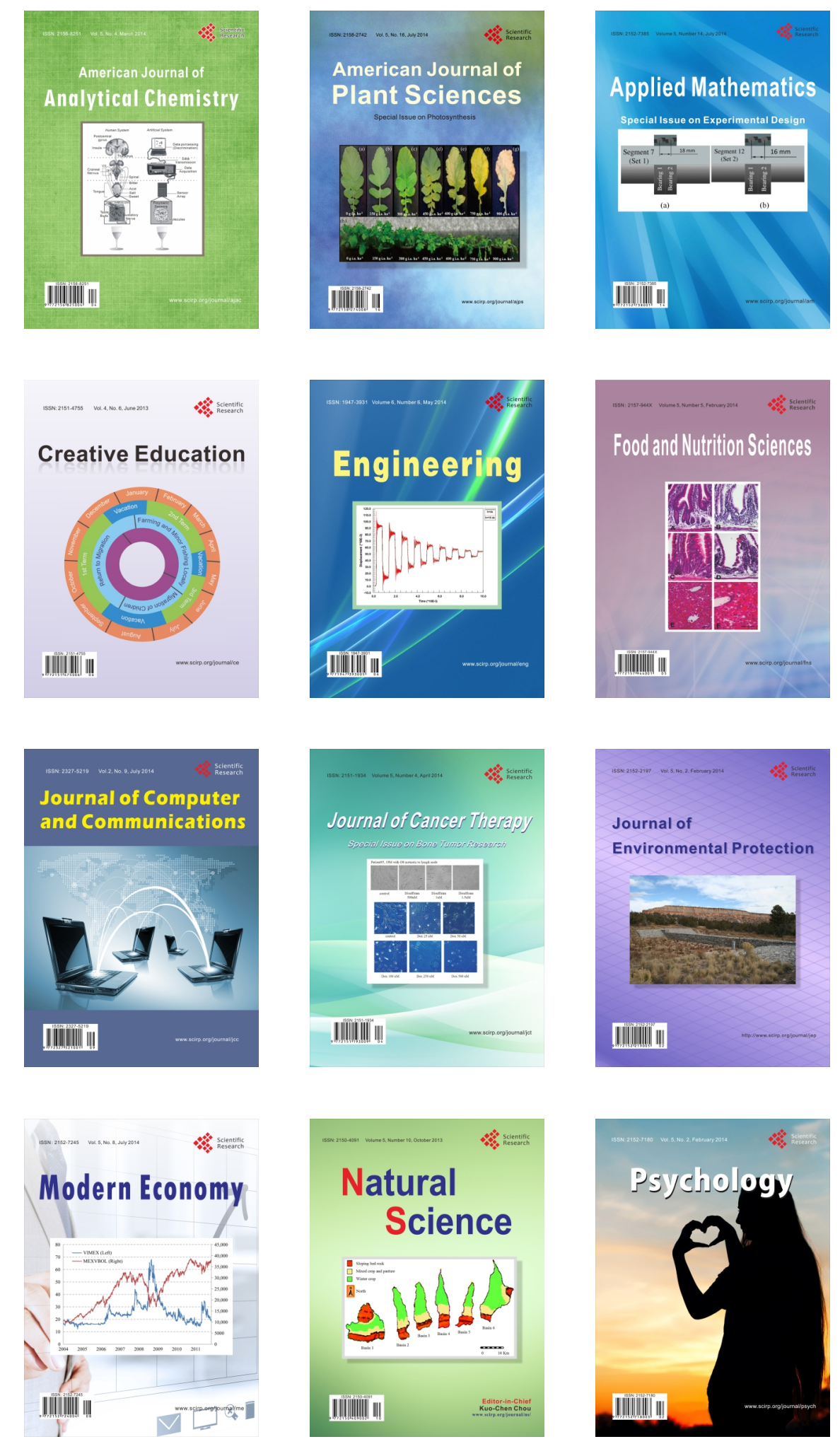